\title{
Understanding Modernist Epic from an Evolutionary Perspective
}

\author{
Büke Sağlam (Santiago de Compostela) \\ Václav Paris: The Evolutions of Modernist Epic. Oxford University Press, 2021. 215 pp. \\ ISBN 978-0-19-886821-7. DOI: 10.1093/oso/9780198868217.001.0001 (pdf).
}

In his detailed, original, and beautifully analyzed treatise, The Evolutions of Modernist Epic, Václav Paris discusses the curious connection between the modernist epic and Darwin's evolutionary theory. As he states at the very beginning of the book:

This book tells the story of the early twentieth-century encounter between epic and evolution. Each of its four chapters focuses on one or two innovative literary works from different national settings: the United States, Ireland, Czechoslovakia, England, and Brazil. In tracing the interaction between epic and evolution across this geographically extended range of texts, its principal aim is to scope out a new approach to comparative modernism. (Paris 2021, 1)

Using an interdisciplinary approach, Paris investigates the representations and development of modernist epic in different cultures and languages by analyzing the (anti)-Darwinist ideas hidden in their complex structures. By comparing these seemingly different works, he offers a comprehensive reading, using the ideas of different disciplines such as anthropology, sociology, and literature.

Václav Paris is an assistant professor at the City College of New York, and his research areas include modern studies, literary theory, literature and the environment, as well as Czech culture and literature and evolutionary science ${ }^{1}$. Indeed, in The Evolutions of Modernist Epic, it is possible to see his expertise in each area. The book is divided into four chapters. The first chapter, "Be-

1 See https://www.ccny.cuny.edu/profiles/václav-paris. ginning Again with Modernist Epic: Gertrude Stein's The Making of Americans", examines one of the most interesting examples of modernist epic, which perfectly reverses the established rules of the epic genre as well as the genre's link to Darwin's evolutionary theory. Paris emphasizes Stein's effort in narrating an alternate history of the United States by challenging the strict heterosexual and patriarchal connotations of Darwinism. In the following chapter, "Joyce's Atavism and the New Ireland", Paris continues with a very famous example, "Ulysses". Just like in the case of Stein, Paris points out, Ulysses' sophistication derives from Joyce's peculiar style and, more importantly, from his objection to social Darwinism and other Darwinist thoughts such as virility and progression. Chapter 3, "Survival of the Unfittest on the Eastern Front: The Good Soldier Švejk", offers another aspect of anti-Darwinist thought through Jaroslav Hašek's strange, unique, and eccentric modernist work. As the title clearly suggests, this chapter challenges the main idea of natural selection, which is the "survival of the fittest", which constitutes one of the main themes of The Good Soldier Švejk. As Paris explains, by creating a protagonist who is a seemingly dumb, incompetent, and passive "soldier" during the World War I, who somehow managed to survive, Hašek did not only create an anti-hero but also rejected Darwinist qualities of a typical "survivor", who should be strong, intelligent, competent, and dominant. Moreover, through antimilitarist ideas, the book again attacks the "alpha male warrior" archetype, which is a core element of the epic genre and an important factor of evolutionary ideas. Chapter 4, "Comparing Tales of the Tribe: Macunaima and Orlando", offers a comparative reading of two geographi- 
cally very different works; the first one sets in Brazil and the latter in England. Paris shows some of the very similar points between the work of Mário de Andrade and that of Virginia Woolf, such as their opposition against the fascism of the era, which used evolutionary thoughts to create its ideological basis. Both authors chose "hybrid" protagonists (Woolf's Orlando changes sex and de Andrade's Macunaíma changes race) to protest social Darwinist view.

Václav Paris' book is very well-written for various reasons: First of all, his selection of the works is not random; each book he analyzed served as a conscious response to various Darwinist thoughts ${ }^{2}$. While the idea of the "survival of the fittest" is a common misconception according to the Stanford neuroscientist Robert Sapolsky, as he states in Behave?: "We start by trashing some common misconceptions. First, that evolution favors survival of the fittest. Instead, evolution is about reproduction, passing on copies of genes. An organism living centuries but not reproducing is evolutionarily invisible." (Sapolsky 2018, 328), as Paris clearly explains, none of the works misinterpreted the Darwinist theory, they only tried to "reverse" it:

But while Švejk's story inverts contemporary social Darwinist, fascist, and eugenic expectations of how survival of the fittest might function, it is important to note that it does not upset the basic theory itself, since, as any student of Darwin will explain, Darwin adopted Spencer's term the "fittest" to mean simply and tautologically those best adapted to the conditions..$^{4}(2021,116-117)$

2 Today we know that the current evolutionary theory, Neo-Darwinism, developed and polished the old Darwinist theory, especially with the introduction of genetics.

3 Sapolsky, Robert: Behave: The Biology of Humans at Our Best and Worst. London: Vintage, 2018.

4 At this point, it is important to add the following explanation by Sapolsky: "Another misconception is that evolution can select for preadaptations-neutral traits that prove useful in the future. [...] Related to this is the misconception that living species are somehow better adapted than extinct species. Instead, the latter was just as well-adapted, until environmental conditions changed sufficiently to do them in; the same awaits us." (Sapolsky 2018, 329)
In that sense, it is clearly seen that Paris was very careful and meticulous in selecting and analyzing the works which really did understand Darwinist theory but chose to invert it for their specific arguments. In other words, the selected works do not only challenge the strict rules of Darwinism but offer an alternate and - more flexible - understanding of the theory. Thus, Paris' aim was not simply to find anti-Darwinist traits in modernist epic but drawing attention to "anti-categorical" or "anti-labelling" nature of this genre.

Secondly, Paris' cautious and conscious approach is worth appreciating. Throughout the book he tries to find a middle ground regarding the relation between evolution and epic. As he states in the introduction: "Our course is set between two opposing standpoints on the question of the relation of epic to evolution. On one side [...] epic and evolution have almost nothing in common. [...] On the other side [...] evolution and epic have almost everything to do with each other [...]." (4) As he further comments: "There are hazards on both sides." (6) So, rather than taking a side, Paris simply analyzes this very complex love-hate relationship between epic and evolution which is perfectly represented in modernist epic.

Another important point worth mentioning is Paris' courage. That is, the courage to sail away from the safe harbor of using the ideas of globalisation, imperialism, or post-colonialism while dealing with the world literature. By counting on Darwinism, which somehow creates a basis for all these mentioned concepts, Paris paints a bigger and more profound picture of world literature. As he points out some limitations while commenting on Švejk:

We face the choice, on the one hand, between readings of Hašek as a contemporary of Kafka [...], and readings of Švejk as an ironic national monument. Our current modes of doing world literature and global modernism offer no grounds for reconciling this opposition. I want to suggest, however, that when approaching $\check{S}_{v e j k}$ through the dialectical relation between epic 
and evolution, we don't need to make this choice: that in fact, the two readings come together. In order to see why Svejk constitutes a modernist epic like others of its time, I propose, therefore, to look more carefully at the biological substrate of life - bare life that it thematizes. (115)

In The Evolutions of Modernist Epic, Paris proved to be a true comparatist by bypassing all the artificial limitations and boundaries of various genres, concepts, and ideologies such as Darwinism, epic and world literature in order to analyze personal and unique "evolutions" of individuals represented in selected modernist works. By combining science with literature, he offers an unbiased reading to better understand the human nature. Therefore, any scholar whose research areas include comparative studies, world literature, sociology, anthropology, or evolutionary science will certainly find Paris' book extremely beneficial.

\section{Büke Sağlam, PhD fellow and researcher}

Faculty of Philology, Santiago de Compostela University Department of Spanish, Literary Theory and Linguistics Room B15, Santiago de Compostela, ES

b.saglam@usc.es 